Distribut ion Category: Magnetic Fusion Energy (UC-20)

ANL / FPP / TM-187

ANL/FPP/T:- 187

DES4 015448

ARGONNE NATIONAL LABORATORY

9700 South Cass Avenue

Argonne, Illinois 60439

DESIGN AND ANALYSIS OF A

LOW EDGE TEMPERATURE DIVERTOR

FOR INTOR

by

J. N. Brooks, R. F. Mattas, and $A$. $M$. Hassane $1 n$

Fusion Power Program, ANL

and

M. I. Baskes

Sandia National Laboratories

Livermore, California 94550

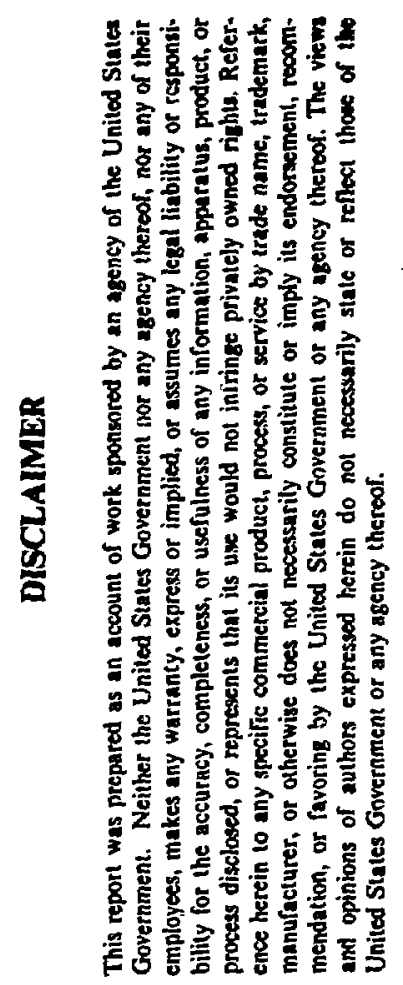

May 1984 


\section{THLS of comrins}

Page

Abstract $\ldots \ldots \ldots \ldots \ldots \ldots \ldots \ldots \ldots \ldots \ldots \ldots \ldots \ldots \ldots \ldots \ldots \ldots \ldots \ldots \ldots \ldots \ldots \ldots \ldots \ldots \ldots \ldots \ldots \ldots \ldots \ldots 1$

1. Introduction.............................................

2. Operating Parameters and Design..................................2

3. Erosion/Re'deposition........................................4

4. Plasma Disruption Erosion....................................9

5. Tritium Permeation...........................................10

6. Materials Gonsiderations......................................12

7. Lifetime Considerations.....................................14

8. Summary and Conclusions....................................16

References...................................................18 


\section{LIST Or TALES}

Table No.

Title

Page

1. INTOR Divertor Plate Erosion/Redeposition Analysis -

No Charge Exchange Sputtering

2. INTOR Divertor Plate Erosion/Redeposition Analysis With CX Sputtering of First Wall

3. Steady State Tritium Inventory and Permeation Rates for the Low Edge Temperature Divertor

4. Properties of Candidate Divertor Collector Plate Materials at $673 \mathrm{~K}$

\section{L.IST OF FIGURES}

Figure No.

Title

1. Flux and temperature distributions for the divertor collector plate, for $T_{e_{0}}=T_{i_{0}}=30 \mathrm{eV}$ at the plate center. Divertor points shown are linearly spaced.

2. Erosion/redeposition predictions for a tungsten coated

8 divertor collector plate.

3. Disruption me1t layer thickness for $\mathrm{Cu}, \mathrm{Ta}$, and $\mathrm{W}$.

4. Disruption vaporization thickness for $\mathrm{Cu}, \mathrm{Ta}$, and $\mathrm{W}$. 


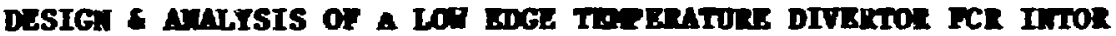

By

J. N. Brooks, R. F. Mattas, and A. H. Hassanein

Pusion Power Program

Argonne National Laboratory

Argonne, Illinois 60439

and

H. I. Baskes

Sandia National Laboratory

Livermore, California 94550

\begin{abstract}
ABSTACT
A low plasma edge temperature regime has been proposed for the INTOR divertor in order to minimize erosion on the collector plate. We tave exanIned the design and lifetine issues of a divertor plate rpitating in such a regime. These issues include the cholce of materials, erosion due to sputtering and disruptions, thermal response, and tritium permeation. We have concluded that a tungsten coated, copper substrate plate offers the possibility of low erosion coupled with good thermal properties. However, there are many unresolved issues with this and other plate configurations. These issues include the transfer of first wall sputtered material to the plate, tritium permeation into the coolant, materials problems such as radiation swelling, embrittlement, and joinling.
\end{abstract}

\section{Introdaction}

The INTOR reactor design study has Identified the erosion of the impurity control system surface as a critical design 1ssue [1]. A Low temperature divertor regime ( $\mathrm{T}_{\mathrm{e}}<50 \mathrm{eV}$ at the sheath) has been proposed as a way of minimizing erosion, by reductng particle inpingesent energies. As shown by both code calculations and experiments, such a regine appears to be obtainable through high recycling of hydrogen in the divertor channel.

We have examined the use of a divertor collector plate in this regine with a focus on the outer collector plate, since this is exposed to the highest fluxes. Because much of the plasma data are st11l prelininary, sone of the key plasma related paraneters, such as first wall sputtering, are 
uncertain, and prelininary aodels have been used to identify the magnttude of the problem. The nain lssues examined in this study are erosion, naterial cholc's, tritium permeation, and overall lifetine.

We have concluded that the low teaperature regive nay well pernit the use of a high-Z plaswa side material, specifically tungsten, to minimize sputter1ng. Unfortunately, however, there are st11l unresolved questions about the divertor lifetime and performance, even if erosion is reduced.

\section{Operating Paraneter: and Design}

The plasma operating parameters for this study were taken fron those provided at a recent INTOR workshop [2]. The plasma temperature $T_{0}$ at the plate, just prior to the sheath region at the plate center, is an important parameter and has been varied from 20-50 ev in this study. Figure 1 shows the operating conditions for $T_{0}=30 \mathrm{eV}$, over the middle $60 \mathrm{~cm}$ of the $1 \mathrm{~m}$ wide divertor plate. A total of $40 \mathrm{MW}$ of power flows to the plate. Both particle and energy fluxes are given by asymetric gaussian distributions which appear to be characterized by simaller scrapeoff distances than for higher temperature regtmes. The reduced scrapeoff distances result in an increased heat flux, on the plate, of - $5 \mathrm{~mW} / \mathrm{m}^{2}$ compared to previous designs. The helium flux is equal to $5 \%$ of the DT flux. The total DT current to the plate and the particle fluxes scale inversely with temperature, and it is thus characteristic of the low temperature regime that the particle fluxes are very high. The spatial variations of density and temperature are somewhat ambiguous at this time, and the simplified profiles show in Fig. 1 have been used according1y. The erosion results are fairly insensitive to the exact density and terperature profiles except possibly at the ends of the plate, and further study of this issue is needed.

The present effort has emphasized design trade-offs for the divertor collector plates. The basic configurations renain an actively cooled plate consisting of a plasma side material bonded to a structural heat sink. Three variations on this configuration were examined during this study. The sifplest design is a bare copper alloy heat sink. This type of design is desirsile from a fabrication standpoint, but there are concerns about the use of =jeper as a plasma side material. The next design consists of a tantalum =iszing which is bonded to stainless steel. In this design, tantalun serves 


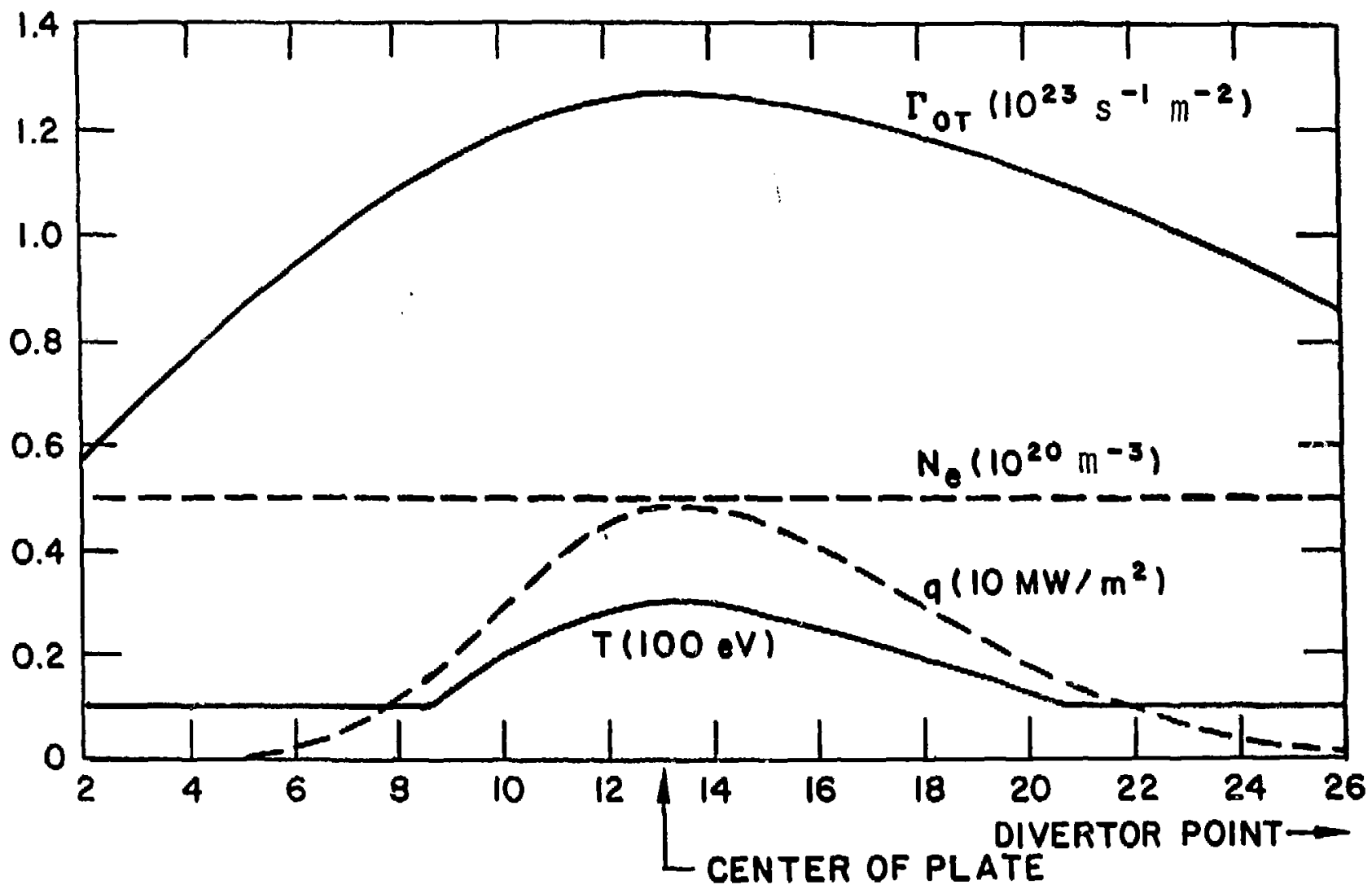

F18. 1. Flux and temperature distributions for the divertor collector plate, $T_{e_{0}}=T_{1_{0}}=30 \mathrm{eV}$ at the plate center. Divertor points shown are linearly spaced. 
as both a plasma side material and a structural material. Stainless steel is selected as the base naterial for the heat sink because of its good fabricability and known resistance to radiation damage. The third design consists of a copper alloy heat sink to which tungsten or tantalum tiles are bonded.

\section{Broeton/ledepoetition}

Erosion/redeposition of the divertor due to sputtering was analyzed using the REDEP computer code, which is described in refs. [3-4]. Briefly, the code computes the self-consistent flux of sputtered neutrals from the divertor due to hydrogen, hellum and self-sputtering, the transport and lonization of sputtered material in the scrapeoff zane, and the resultant inpurity fluxes to the plasma. The net erosion rate is computed as the difference between the sputtered rate and the redeposited rate. The present version of the code, REDEP4 also follows the time evolution of the divertor surface.

Two cases have been considered in the RELEP calculations, Case $A$ in which no charge exchange sputtering $(C X)$ is considered, and Case $B$ in which charge exchange sputtered material from the first wall is transferred to the divertor plate. Nelther case includes charge excinange sputtering of the divertor plate, if any. Table 1 summarizes the REDEP analysis for Case $A$. The materials shown are characteristic of $10 w-Z$ (Be), medium $Z$ (TI) and high $-Z$ (Mo, W) materials. In particular, erosion of vanadiun should be very similar to titanium in its performance, and tantalum should be simflar to tungsten. The parameters shown In Table 1 are for the center of the divertor plate, which generally suffers the worst gross and net erosion rates.

Incidence angles of $60^{\circ}$ from the normal were used to conpute all sputterIng coefficients. As shown, for $B e$, the net erosion rates diminish with increasing plasma temperature. This is due to higher redeposited fractions, which increase with temperature because of increasing electron impact lonizatIon rates. However, the net erosion rate of $4 \mathrm{~cm} / \mathrm{gr}$ at $50 \mathrm{eV}$ is $\mathrm{sti11}$ unacceptable. For titanium, the combination of higher nass and larger Ionization rate coefficients, than $\mathrm{Be}$, results in a mean free path for sputtered material that is roughly five times sualler than Be. As a result, redeposited fractions approach unity. The net erosion rates are acceptable over the range shown. However, the very high gross sputtering rates give rise to obvious concerns about the physical properties of the redeposited material. 
Table 1.

INTOR Divertor Plate Erosion/Redeposition Analysis - No Charge Exchange Sputtering

\begin{tabular}{|c|c|c|c|c|c|c|c|c|}
\hline $\begin{array}{l}\text { Plate } \\
\text { Coating } \\
\text { Material }\end{array}$ & $\begin{array}{c}\text { Plasina Edge } \\
\text { Temperature } \\
\text { (At Separatrix) } \\
(\mathrm{ev})\end{array}$ & $\begin{array}{r}\text { Sput } \\
\mathrm{Y}_{\mathrm{DT}}\end{array}$ & $\begin{array}{l}\text { Sering Coe } \\
Y_{\alpha}\end{array}$ & $\begin{array}{l}f f \\
x_{z}^{*}\end{array}$ & $\begin{array}{l}\text { D-T Flux } \\
\text { to Divertor } \\
\text { Plate Center } \\
10^{23} \mathrm{~m}^{-2} \mathrm{~s}^{-1}\end{array}$ & $\begin{array}{l}\text { Gross Sputtering } \\
\text { Rate at Divertor } \\
\text { Center Due to } \\
\text { DT + He } \\
\mathrm{cm} / \mathrm{yr}\end{array}$ & $\begin{array}{l}\text { Total Gross } \\
\text { Sputtering Rate } \\
\text { at Divertor } \\
\text { Center } \\
\mathrm{cm} / \mathrm{yr}\end{array}$ & $\begin{array}{l}\text { Net Erosion } \\
\text { Rate at } \\
\text { Divertor } \\
\text { Center } \\
\text { cin/yr }\end{array}$ \\
\hline Beryllium & $\begin{array}{l}20 \\
30 \\
40 \\
50\end{array}$ & $\begin{array}{l}.071 \\
.087 \\
.095 \\
.098\end{array}$ & $\begin{array}{l}.15 \\
.18 \\
.20 \\
.21\end{array}$ & $\begin{array}{l}.45 \\
.55 \\
.62 \\
.66\end{array}$ & $\begin{array}{l}1.9 \\
1.3 \\
.95 \\
.76\end{array}$ & $\begin{array}{l}382 \\
313 \\
256 \\
212\end{array}$ & $\begin{array}{l}680 \\
688 \\
666 \\
624\end{array}$ & $\begin{array}{r}14.0 \\
9.1 \\
5.4 \\
4.1\end{array}$ \\
\hline Titanium & $\begin{array}{l}20 \\
30 \\
40\end{array}$ & $\begin{array}{l}.011 \\
.024 \\
.038\end{array}$ & $\begin{array}{l}.038 \\
.061 \\
.082\end{array}$ & $\begin{array}{l}.49 \\
.71 \\
.92\end{array}$ & $\begin{array}{l}1.9 \\
1.3 \\
.95\end{array}$ & $\begin{array}{l}134 \\
190 \\
225\end{array}$ & $\begin{array}{l}266 \\
658 \\
2750\end{array}$ & $\begin{array}{l}.025 \\
.056 \\
.1: 2\end{array}$ \\
\hline Molybdenum & $\begin{array}{l}20 \\
30 \\
40\end{array}$ & $\begin{array}{l}9.9 \times 10^{-4} \\
3.3 \times 10^{-3} \\
5.4 \times 10^{-3}\end{array}$ & $\begin{array}{l}6.3 \times 10^{-3} \\
.014 \\
.023\end{array}$ & $\begin{array}{l}.43 \\
.60 \\
.79\end{array}$ & $\begin{array}{l}1.9 \\
1.3 \\
.95\end{array}$ & $\begin{array}{l}12 \\
25 \\
31\end{array}$ & $\begin{array}{l}21 \\
64 \\
142\end{array}$ & $\begin{array}{l}m 0 \\
m 0 \\
m 0\end{array}$ \\
\hline Tungsten & $\begin{array}{l}20 \\
30 \\
40 \\
45\end{array}$ & $\begin{array}{c}0 \\
0 \\
0 \\
1.5 \times 10^{-3}\end{array}$ & $\begin{array}{c}8.4 \times 10^{-5} \\
.0013 \\
.0024 \\
.0029\end{array}$ & $\begin{array}{l}.45 \\
.64 \\
.82 \\
.91\end{array}$ & $\begin{array}{l}1.9 \\
1.3 \\
.95 \\
.84\end{array}$ & $\begin{array}{l}.04 \\
.40 \\
.57 \\
1.3\end{array}$ & $\begin{array}{l}.07 \\
1.1 \\
3.1 \\
13.7\end{array}$ & $\begin{array}{l}m 0 \\
n 0 \\
n \\
m 0\end{array}$ \\
\hline
\end{tabular}

* Self-sputtering coefficient for redeposited material. 
The high gross spittering rate for Ti is due to both a high DT + He sputtering rate, and high self-sputtering rates of the redeposited lons. At an edge temperature of $>40 \mathrm{eV}$, the self-sputtering coefficient of redeposited $\mathrm{T} 1$ approaches unity, leading to a runaway self-sputtering cascade. Thus $T i$ is 11 inted to temperatures below about $50 \mathrm{eV}$, based on the models used for charge state, sheath potential, etc.

For tungsten, the erosion results are quite good over the low temperature range $\left(T_{e}<50 \mathrm{eV}\right)$, with essentially zero net erosion predicted. In most cases Impinging DT energies are below the sputtering threshold with sputtering due only to the $5 \%$ hellum component, and self-sputtering. At edge temperatures $>50 \mathrm{ev}$, self sputtering approaches unity, leading to a runaway selfsputtering cascade.

The results for molybdenum are intermediate to $T i$ and $W$ in the sense that the grosi; rates are significant but stfll about one tenth that of $T 1$. Net rates are essentially zero. For all materials, alnost no plate sputtered impurities reach the main plaswa.

Table 2 summarizes the divertor plate erosion for $T_{0}=30 \mathrm{ev}$, at the center, when CX sputtering of the first wall is 1ncluded. In the absence of better data, an ad-hoc model was used for these computations. The cX current to the first wall was taken as 57 of the DT current to both divertor plates. Sputtering coeffictents for $C X$ neutrals on the wall were computed at an energy of $300 \mathrm{eV}$ and an angle of $45^{\circ}$. This energy is higher than energles associated with most of the scrapeoff region but can arfse because of the introduction of refueling gas into the plasma proper. One half of the sputtered material from the first wall was assumed to flow to each divertor plate. The flux of such materials on the divertor plate was ussumed to have the same spatial form as the DT f1ux.

As shown in Table 2, the use of low- to medium-z wall materials nay result in unacceptably high growth rates of material on the divertor plate. For the cases of an Fe wall (i.e. stainless steel) and a divertor plate, the plate surface would essentially be converted to Fe in several weeks. Even a factor of ten reduction in the transfer rate of Fe would result in a problem.

The gross sputtering and net growth rates of a tungsten coated wall and divertor combination are shown in Fig. 2. Even with a sheath potential of 3 
Table 2.

INTOR Divertor Plate Erosion/Redeposition Analysis - With CX Sputtering of First Wall Plasma Edge Temperature (At Separatrix) $=30 \mathrm{eV}$

\begin{tabular}{|c|c|c|c|c|c|}
\hline $\begin{array}{l}\text { Plate } \\
\text { Coating } \\
\text { Material }\end{array}$ & $\begin{array}{l}\text { Wall } \\
\text { Coating } \\
\text { Material }\end{array}$ & $\begin{array}{l}\text { CX Sputtering } \\
\text { Rate on First } \\
\text { Hall, } I_{2}^{\text {CX }}\end{array}$ & $\begin{array}{l}\text { Wall Material to } \\
\text { Plate Material } \\
\text { Sputtering Coeff. } \\
\text { at Separatrix } \\
\qquad Y_{Z_{P}}\end{array}$ & $\begin{array}{l}\text { Total Gross } \\
\text { Sputtering Rate } \\
\text { at Divertor } \\
\text { Center } \\
\mathrm{cm} / \mathrm{yr}\end{array}$ & $\begin{array}{l}\text { Net Growth } \\
\text { Rate at } \\
\text { Divertor } \\
\text { Center } \\
\mathrm{cm} / \mathrm{yr}\end{array}$ \\
\hline $\mathrm{Be}$ & $\mathrm{Be}$ & $2.56 \times 10^{22}$ & .65 & 707 & 20,5 \\
\hline Ti & $\mathrm{Ti}$ & $1.63 \times 10^{22}$ & 3.9 & 905 & 18.5 \\
\hline Mo & Mo & $4.1 \times 10^{21}$ & 3.0 & 25 & 4.1 \\
\hline $\mathrm{w}$ & $\mathrm{Fe}$ & $8.2 \times 10^{21}$ & .26 & 8.5 & 12.5 \\
\hline $\mathbf{W}$ & $\mathbf{W}$ & $3.52 \times 10^{20}$ & 3.0 & 4.1 & .36 \\
\hline
\end{tabular}




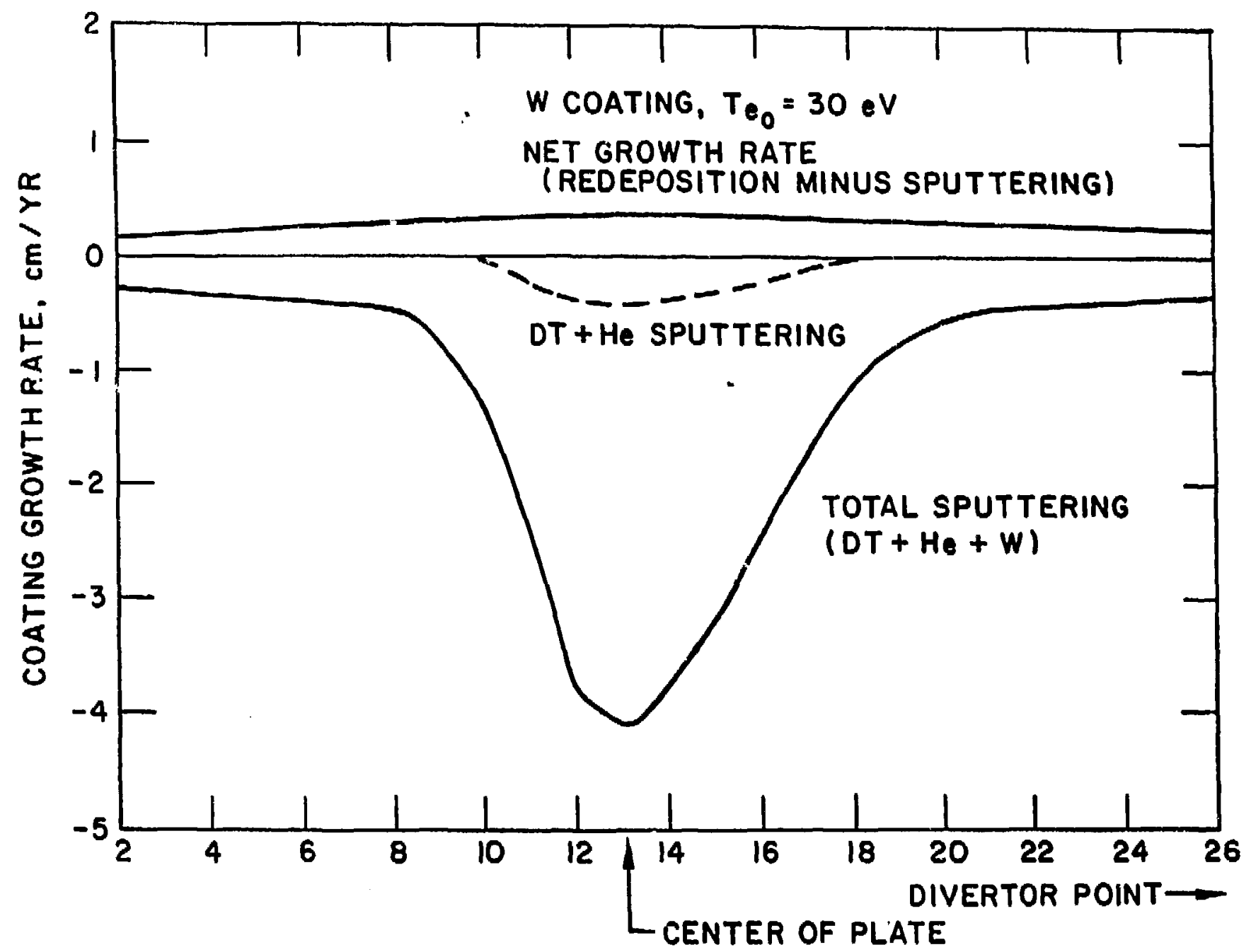

Fig. 2. Erosion/redeposition predictions for a tungsten coated divertor collector plate. 
$T_{e}$, the sputtering cosficients for $D T$ on $W$ are below the sputtering threshold; the curve labeled "DT + He sputtering" is therefore due entirely to He sputtering. The difference between the two sputtering curves in Fig. 2 represents the effects of self sputtering. This arises from two sources: (1) W ions sputtered from the plate, ionized and returned to the plate and (2) W lons from first wall sputtering. The two sources of lons have substantially different impingement energles since first wall sputtered material reacles a higher charge state and acquires the DT sound velocity. The peak sputtering rate is $\sim 4 \mathrm{~cm} / \mathrm{yr}$ at the center. Because of the high plasma density, and the high mass of tungsten, the mean free paths of sputtered $W$ atoms to electron impact ionization are short, $\leq .5 \mathrm{~cm}$. Therefore, almost all sputtered $w$ atons return to the surface. The net growth rate of from $2-4 \mathrm{~mm} / \mathrm{yr}$ is due to the transfer of material from the first wall to the divertor. The time evolution of the plate was also computed. At the end of 1 year of operating time, the results are very similar to the results at $t=0$.

For a tungsten coated first wall, therefore, the resuliting growth rate is acceptably low, due essentially to the low value of CX sputtering coefficlent. Also, if CX Imiplngement energles are lower, sputtering coefficients could drop below the threshold for $W$, whereas $F e$ sputtering could still be substantial. A concern with a $W$ first wall however is plasma contamination. Again, results for Mo are Intermediate between $\mathrm{T} 1$ and $W$. More complete Information about the conditions in the edge and scrapeoff regions are needed to thoroughly assess this problem.

\section{Plasa Discuption Brosion}

Plasma disruptions remain a sertous concern for tokanak fusion reactors. The surfaces of the divertor and first wall are subject to large thermal energy dumps during the disruptions. This large energy deposition on the surfaces could result in vaporization and melting of these materials leading to large erosion rates. For the present study, the response of copper, tantalum, and tungsten as potential divertor coating materials during a plasma disruption was examined. The calculation was done parametrically as a function of the energy density for two different disruption times, 5 and 20 ms. The reference values of the collector plate disruption parameters are 230 $\mathrm{J} / \mathrm{cm}^{2}$ deposited in $20 \mathrm{~ms}$ as described In ref. [5]. The computer code $A^{*}$ THERMAL and the models used to calculate the thernal response and erosion 
rates are described elsewhere [6]. The calculations are made assuming no interactions between the vaporized materials with the incoming plasma lons, and the intial temperature of the divertor plate materials is taken to be $300^{\circ} \mathrm{C}$. The disr-ption energy density is varied up to $1100 \mathrm{~J} / \mathrm{cm}^{2}$ to account for the uncertainty of the total energy deposited, peaking factor, and area of deposition.

The melting zone thickness for $\mathrm{Cu}, \mathrm{Ta}$, and $\mathrm{W}$ as a function of disruption energy density is shown in Fig. 3 for 5 and 20 ms disruption time. Copper shows the largest melt layer thickness among the three materials, and for an energy density of about $1000 \mathrm{~J} / \mathrm{cm}^{2}$ deposited in $20 \mathrm{~ms}$, a melt layer thickness of $1 \mathrm{~mm}$ is predicted. Tungsten exhibits the smallest melt layer thickness and for $20 \mathrm{m \varepsilon}$ disruption time, no melting is predicted to occur for energy densities less than $700 \mathrm{~J} / \mathrm{cm}^{2}$. For $5 \mathrm{~ms}$ disruption time copper starts to melt for energy densities about $200 \mathrm{~J} / \mathrm{cm}^{2}$, and it increases sharply for hf.gher energy densities. Such large melt layer thicknesses for copper are 11kely to be unstable under the magnetic forces and torques resulting from the plasma disruption [7].

Figure 4 shows the material vaporized during the disruption as a function of energy density and disruption time. Copper also shows the largest vaporization loss and tungsten the lowest. Shorter disruption times increase vaporization losses and reduce the threshold energy needed to cause significant vaporization. For $20 \mathrm{~ms}$ disruption and energy densities up to $1100 \mathrm{~J} / \mathrm{cm}^{2}$ no vaporization losses occur from tungsten. Based on these results, tungsten withstands more severe disruption conditions than efther copper or tantalum. Howejer, all three materials are predicted to exhibit no vaporization losses for the reference disruption conditions.

\section{Tritiu Permeation}

Tritium permeation in the divertor and first wall has been evaluated for several materials combinations using the DIFFUSE code [8]. The divertor chamber and first wall will be subjected to an intense flux of low energy DT particles that will be implanted into the exposed surfaces. The DIFFUSE code predicts the amount of tritium that is either released from the plasma side surface, retained in the structure, or permeates through to the coolant. For these calculations it has been assumed that the surfaces of the material are very clean, which results in high tritium release rates at the surface, and 

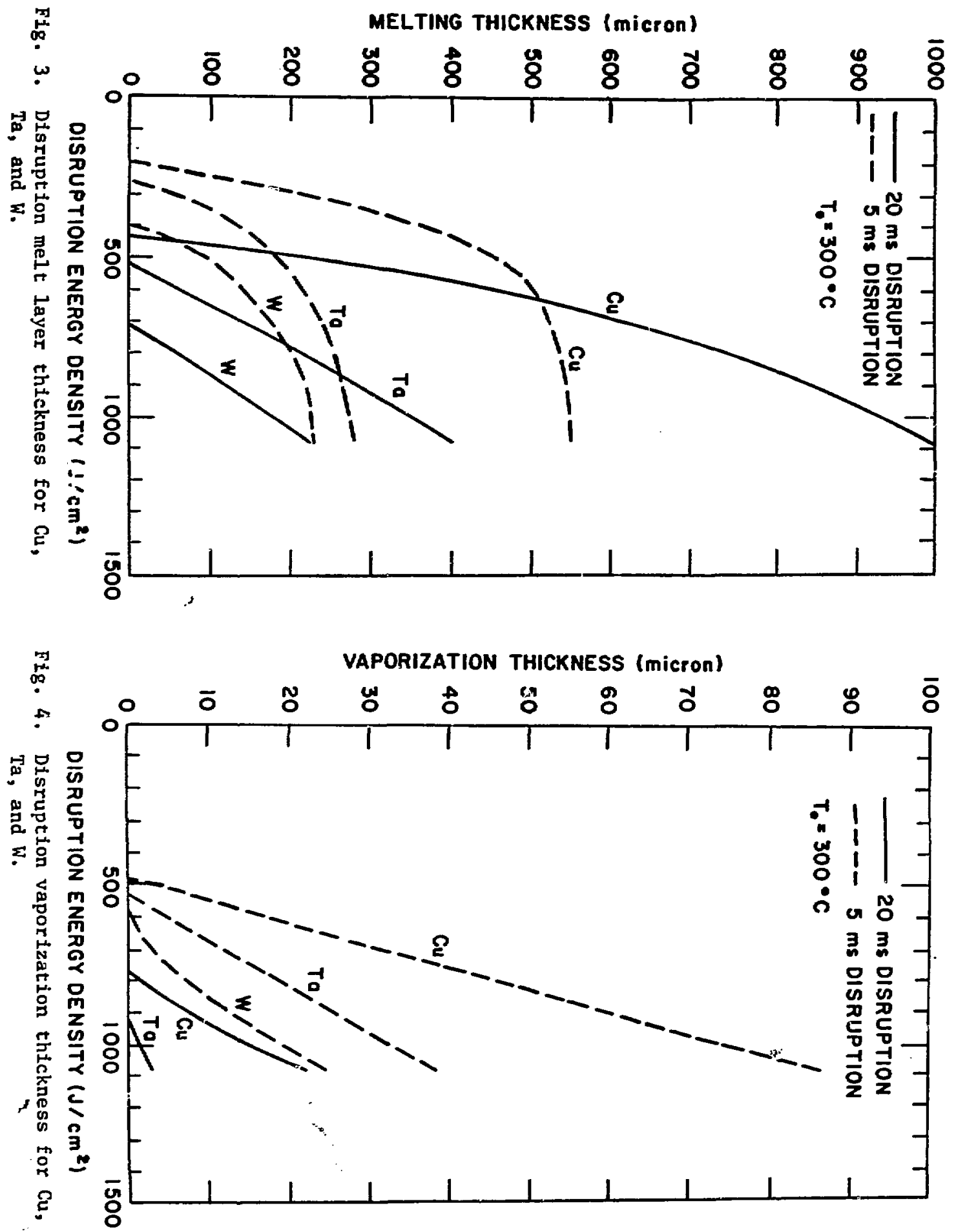
that there are no neutron damage traps in the material, which results in lower values for retained tritium. Some of the materials data used for the calculations are given in ref. [5].

The predicted steady state retention and permeation rates are presented in Table 3. The steady state rates will be reached in the divertor in less than one year of operation. The rates tend to be higher for the $\mathrm{CX}$ areas (1.e. the divertor channel walls) because the particle current is higher and the surface temperature is lower. In the cases of either the pure tantalum or tantalum bonded to copper plates, the total tritium inventory is excessively high. The numbers shown in Table 3 are unrealistic in the sense that tantalum will be transformed to a hydride long before these inventories are reached. The results Indicate, however, that tantalum cannot be used in this environment. The predicted values for the retention and permeation of tungsten bonded to copper are much lower, but the combined permeation rate for the collector plate and charge exchange neutral areas is still $-6 \times 10^{5} \mathrm{ct} / \mathrm{d}$, which Is considered to be excessive. The impact of this level of permeation on the tritium cleanup, systems needs to be assessed. (Note that the predicted permeation rate for $\mathrm{Ta} / \mathrm{Cu}$ is less than that predicted for $\mathrm{W} / \mathrm{Cu}$ due to the lower chemical potential produced in Ta by the implanted hydrogen.) The permeation rate for the stainless stee? first wall is predicted to be quite low and therefore is not:expected to be a concern.

\section{Materials Considerations}

Based on the erosion results, two high-Z materlals, tungsten and Ta-10w, and two structural materials, Type 316 statnless steel and $\mathrm{Cu}-.5 \mathrm{Be}-2 \mathrm{NI}$, have been considered. The thermophysical properties of the candidate metals were evaluated, and a subset of the properties is shown in Table 4. The copper alloy exhibits the highest thermal conductivity, but it also has the highest coefficlent of thermal expansion. Type 316 stalnless steel has the poorest thermophysical properties which precludes its use as a plasma side material. Representative values for the tensile properties of the candidate materials are given in Table 4. Tungsten in the recrystallized form exhibits the lowest tensile strength. The high ductile-brittle transition temperature in tungsten means that the ductility is almost zero at room tenperature. The other alloys exhibit high tensile, strength and adequate ductility at the temperatures of 
Table 3.

Steady State Tritium Inventory and Permeation Rates for the Low Edge Temperature Divertor

\begin{tabular}{|c|c|c|c|c|}
\hline Component & Materials & $\begin{array}{l}\text { Thickness } \\
(\mathrm{mm})\end{array}$ & $\begin{array}{c}\text { Steady State } \\
\text { Permeation Rate } \\
\mathrm{Ci} / \mathrm{d}\end{array}$ & $\begin{array}{c}\text { Inventory } T \\
\text { gms }\end{array}$ \\
\hline Collector plate & $\mathrm{Ta}$ & 4 & $1.3 \times 10^{7}$ & $1.5 \times 10^{6}$ \\
\hline Collector Plate & $\begin{array}{l}\mathrm{Ta} \\
\mathrm{Cu}\end{array}$ & $\begin{array}{l}2 \\
4\end{array}$ & $4.3 \times 10^{-2}$ & $1.5 \times 10^{6}$ \\
\hline Collector plate & $\begin{array}{l}\mathbf{W} \\
\mathbf{C u}\end{array}$ & $\begin{array}{l}2 \\
4\end{array}$ & $2.2 \times 10^{4}$ & 5 \\
\hline CX areas & $\mathrm{Ta}$ & 4 & $1.3 \times 10^{9}$ & $1 \times 10^{8}$ \\
\hline CX areas & $\begin{array}{l}\mathrm{Ta} \\
\mathrm{Cu}\end{array}$ & $\begin{array}{l}2 \\
4\end{array}$ & $2.6 \times 10^{-4}$ & $5 \times 10^{7}$ \\
\hline CX areas & $\begin{array}{l}\mathrm{W} \\
\mathrm{Cu}\end{array}$ & $\begin{array}{l}2 \\
4\end{array}$ & $4.4 \times 10^{4}$ & 150 \\
\hline Firet wall & SS & 12 & $2.6 \times 10^{0}$ & 150 \\
\hline
\end{tabular}


Interest. The copper alloy has the lowest operating temperature limit due to a rapid loss of tensile strength at $350-400^{\circ} \mathrm{C}$. The thermal stress coefficient is also shown in Table 4. Cu-0.5Be exhibits the highest coefficient primarily because of its high thermal conductivity. The high-z metals also exhibit high values for the thermal stress coefficient, whereas the coefficient for Type 316 stainless steel is approximately a factor of 10 less than the other materials. With the exception of Type 316 stainless steel, the irradiation effects database is 1imited. The major concern is the loss of ductility which accompanies low teruperature irradiation.

\section{Lfetine Considerations}

The major purpose of this engineering study is to determine the best impurity control system for INTOR. The desired engineering features for the impurity control system are low cost, minimum impact on other reactor systems, maintainability, and extended lifetime. The motivation for examining the low edge temperature is the potential for a greatly extended iffetime compared with the medium edge temperature limiter system where more rapid sputtering erosion is predicted. There are, however, additional factors that influence lifetime besides sputtering erosion, and th is not clear that even the complete elimination of sputtering will result in a longer lifetime. other potential fallure modes for the divertor are excessive dimensional change due to radiation swelling or creep, debonding between the plasma side material and heat sink, rupture or cracking of the heat sink, and severe embrittlement which prevents the system fror withstanding off-normal events. Accurate predictions of the times to failure via these modes depends on the accuracy of the material properties data base. Important properties in this regard are fatigue and crack growth behavior, bond strength, radiation swelling, radiation creep, and the effects of radiation on the thermophysical and mechanical properties. Unfortunately, the materials that have been selected for examination are not well characterized in several areas. In particular, the radiation effects data base is very small, and it is not possible- to accurately predict the swelling or embrittlement behavior of these materials. There are also few data avallable concerning the bond properties, since fabrication development is at an early stage. Therefore, it is not posisible to nake reasonable lifetime predictions for the divertor system, at present. Although the limiter faces much of the same issues as the divertor, the limiter is 
Table 4.

Properties of Candidate Divertor Collector Plate Materials at $673 \mathrm{~K}$

\begin{tabular}{|c|c|c|c|c|}
\hline Property & Tungsten & $\mathrm{Ta}-10 \mathrm{~W}$ & 316 SS & $\mathrm{Cu}-0.5 \mathrm{Be}-2 \mathrm{Ni}$ \\
\hline $\begin{array}{l}\text { Thermal cond. } \\
(\mathrm{w} / \mathrm{mk})\end{array}$ & 135 & 63 & 20 & 267 \\
\hline $\mid \begin{array}{l}\text { Therma } 1 \text { Exp. } \\
\left(x \quad 10^{-6} / k\right)\end{array}$ & 4.5 & 6.7 & 17.5 & 18.6 \\
\hline $\begin{array}{l}\text { Density } \\
\left(\mathrm{g} / \mathrm{cm}^{3}\right)\end{array}$ & 19.15 & 16.4 & 7.8 & 8.6 \\
\hline $\begin{array}{l}\text { Elastic Modulus } \\
\text { (GPa) }\end{array}$ & 390 & 170 & 184 & 106 \\
\hline $\begin{array}{l}\text { Specific Heat } \\
(\mathrm{J} / \mathrm{kg} \mathrm{K})\end{array}$ & 141 & 153 & 554 & 427 \\
\hline $\begin{array}{l}\text { Tensile Strength } \\
(\mathrm{MPa})\end{array}$ & $350^{a}$ & $996^{b}$ & $681^{c}$ & $607^{\mathrm{d}}$ \\
\hline Poisson's Coef. & .286 & $0.3^{e}$ & .293 & $0.3^{\mathrm{e}}$ \\
\hline $\begin{array}{l}\text { Thermat stress } \\
\text { Coef. }\end{array}$ & $2.69 \times 10^{4}$ & $5.51 \times 10^{4}$ & $4.29 \times 10^{3}$ & $8.22 \times 10^{4}$ \\
\hline Composition & $\begin{array}{c}\text { Pure tungsten } \\
\text { Bal. Ta }\end{array}$ & $\begin{array}{l}10 \% \mathrm{~W}- \\
2.5 \mathrm{Ho} . \\
\mathrm{Ba1} . \mathrm{Fe}\end{array}$ & $\begin{array}{c}16 \mathrm{Cr}, 14 \mathrm{Ni} \\
0.5 \mathrm{Be} \\
\mathrm{Ba} 1 . \mathrm{Cu}\end{array}$ & 2. $\mathrm{Ni}$ \\
\hline
\end{tabular}
a Recrystallized.
b As wraught.
c $20 \%$ cold-worked.
d Heat treated.
e Assumed.
$\mathrm{f} \frac{\mathrm{k} \times \mathrm{UTS}}{a \times \mathrm{E}}$ 
simpler and less expensive. Therefore, the choice of a divertor would be made on the basis of a significantly longer iffetime. The potential iffetime advantages of the low edge temperature a.mertor over the limiter can only be determined when additional materfals information becomes avaflable.

\section{Sumary and Conclustons}

The work to date indicates that the low edge temperature divertor has several attractive features. First, calculations indicate that sputtering erosion should be greatly reduced or eliminated for high-z materials. In addition, no melting or vaporization is expected for tungsten or tantalum for the reference INTOR disruption condftions. The absence of erosion adds flexibility to the design of the collector plates and charge exchange neutral areas and allows the use of thin structures that are better able to accommodate high heat fluxes.

There is some concern, however, with regard to sputtered firs: wall particles depositing on the collector plates. A rapid buildup of this paterial on the collector plates could result in short component lifetimes. If should be noted that the physics of the scrapeoff region at the first walf is not well understood. Further analysis is required to completely establish the operating environment for first wall sputtering and particle transport before the magnitude of this problem can be completely assessed.

Tritium permeation and zetention is a major concern for the divertor chamber. The high tritium inventories predicted for tantalum eliminate it as a candidate plasma side material, leaving tungsten as the preferred material. Tungsten bonded to copper is expected to exhibit greatly reduced inventories, but the steady state permeation rate could stfll be significant. The Impact of this permeation on the tritium cleanup systems needs to be assessed.

The Iffetime of the Impurity control components is indefinte at present due to large gaps in the materials data base. Sputtering erosion has been eliminated as a concern, but other factors such as radiation embrittlement, radiation induced dimensional changes, and debonding between the plasma side material and heat sink could lead to fallure. Important properties where information is neeâed are fatigue and crack growth behavior, bond strength, radiation swelling and creep, and the effects of radiation on the thermophysical and mechanical properties. 
In summary, the low edge temperature divertor offers the potential for extended lifetimes and design flexibility in the plasma chamber, but additional experimental and theoretical work is needed before these advantages can be thoroughly evaluated. 


\section{REFEREACES}

[1] INTOR, International Tokamak Reactor, Phase 2A Report, IAEA, Vienna, STI/PUB/638, 1983.

[2] Summary Report, INTOR Critical Issue Group A, January, 1984.

[3] J. N. Brooks, Nucl. Tech./Fusion 4 (1983) P. 33.

[4] J. N. Brooks, J. Nuc1. Mat. $111 \& 112$ (1982) p. 457.

[5] W. M. Stacey, et al., "U.S. FED-INTOR Activity and U.S. Contribution to the International Tokamak Reactor Phase-2A Workshop," FED-INTOR/ICFW/8217 (1982).

[6] A. M. Hassanein, University of Wisconsin Report, UWFDM-465 (1982).

[7] W. G. Wolfer and A. M. Hassanein, J. Nucl. Mat. 111 \& 112 (1982) p. 560.

[8] M. I. Baskes, Sandia National Laboratory Report \# SAND083-8231 (1983). 
Interna 1:

C. Baker

E. Beckjord

C. Boley

J. Brooks

F. Cafasso

Y. Cha

R. Clemmer

D. Ehst

P. Finn

F. Fradin

$Y$. Gohar

L. Greenwood

D. Gruen

A. Hassanein
C. Johnson

J. Jung

M. Kaminsky

S. Kim

R. Kustom

R. Lari

Y. Liu

B. Loomis

S. Majumdar

v. Maroni

R. Mattas

B. Misra

L. Neimark

F. Nichols
J. Norem

R. Nygren

W. Praeg

J. Rest

J. Roberts

D. Smith

H. Stevens

L. Turner

R. Weeks

FP Program (20)

ANL Patent Dept.

ANL Contract File

ANL Libraries (2)

TIS Files (6)

\section{Externa 1:}

DOE-TIC, for distribution per UC-20 (107)

Manager, Chicago Operations Office, DOE

Special Committee for the Fusion Program:

S. Baron, Burns and Roe, Inc., OradeII, N. J.

H. K. Forsen, Bechtel Group, Inc., San Francisco

J. Maniscalco, TRW, Inc., Redondo Beach

G. H. Miley, U. Illinois, Urbana

P. J. Reardon, Brookhaven National Lab.

P. H. Rutherford, Princeton Plasma Physics Lab.

D. Steiner, Rensselaer Polytechnic Inst.

K. R. Symon, U. Wisconsin, Madison

K. I. Thomassen, Lawrence Livermore National Lab.

M. Baskes, Sandia National Labs., Livermore 